\title{
Proviral integrations and expression of endogenous Avian leucosis virus during long term selection for high and low body weight in two chicken lines \\ Sojeong Ka1 ${ }^{1}$, Susanne Kerje ${ }^{1,2,4,5}$, Lina Bornold ${ }^{1}$, Ulrika Liljegren1, Paul B Siegel $^{3}$, Leif Andersson ${ }^{4,5}$ and Finn Hallböök*1
}

Address: ${ }^{1}$ Department of Neuroscience, Uppsala University, Uppsala, Sweden, ${ }^{2}$ Department of Medical Sciences, Uppsala University, Uppsala Sweden, ${ }^{3}$ Department of Animal and Poultry Sciences, Virginia Polytechnic Institute and State University, Blacksburg, USA, ${ }^{4}$ Department of Animal Breeding and Genetics, Swedish University of Agricultural Sciences, Uppsala, Sweden and ${ }^{5}$ Department of Medical Biochemistry and Microbiology, Uppsala University, Uppsala, Sweden

Email: Sojeong Ka - sojeong.ka@neuro.uu.se; Susanne Kerje - Susanne.Kerje@medsci.uu.se; Lina Bornold - lina.bornold@gmail.com; Ulrika Liljegren - ulrika.liljegren@neuro.uu.se; Paul B Siegel - pbsiegel@vt.edu; Leif Andersson - leif.andersson@imbim.uu.se; Finn Hallböök* - finn.hallbook@neuro.uu.se

* Corresponding author

Published: 15 July 2009

Retrovirology 2009, 6:68 doi:10.1186/1742-4690-6-68

This article is available from: http://www.retrovirology.com/content/6/1/68

(c) $2009 \mathrm{Ka}$ et al; licensee BioMed Central Ltd.

This is an Open Access article distributed under the terms of the Creative Commons Attribution License (http://creativecommons.org/licenses/by/2.0), which permits unrestricted use, distribution, and reproduction in any medium, provided the original work is properly cited.

\section{Abstract}

Background: Long-term selection ( $>45$ generations) for low or high juvenile body weight from a common founder population of White Plymouth Rock chickens has generated two extremely divergent lines, the LWS and HWS lines. In addition to a $>9$-fold difference between lines for the selected trait, large behavioural and metabolic differences between the two lines evolved during the course of the selection. We recently compared gene expression in brain tissue from birds representing these lines using a global cDNA array analysis and the results showed multiple but small expression differences in protein coding genes. The main differentially expressed transcripts were endogenous retroviral sequences identified as avian leucosis virus subgroup-E (ALVE).

Results: In this work we confirm the differential ALVE expression and analysed expression and number of proviral integrations in the two parental lines as well as in $F_{9}$ individuals from an advanced intercross of the lines. Correlation analysis between expression, proviral integrations and body weight showed that high ALVE levels in the LWS line were inherited and that more ALVE integrations were detected in LWS than HWS birds.

Conclusion: We conclude that only a few of the integrations contribute to the high expression levels seen in the LWS line and that high ALVE expression was significantly correlated with lower body weights for the females but not males. The conserved correlation between high expression and low body weight in females after 9 generations of intercrosses, indicated that ALVE loci conferring high expression directly affects growth or are very closely linked to loci regulating growth. 


\section{Background}

Selection during more than 45 generations for low or high body weight from a common founder population of crosses among seven lines of White Plymouth Rock chickens has generated two extremely divergent lines; the low (LWS) and high weight selection (HWS) lines. The average body weight of individuals from each line differs by more than 9-times at 56 days, the age of selection. Numerous behavioural, metabolic, immunological, and endocrine differences between lines have evolved during the course of the selection experiment [1-4]. Among the obvious correlated responses to the selection for body weight were differences in feeding behaviour and food consumption. While HWS chickens are hyperphagic compulsive eaters and accumulate fat, LWS chickens are lean with low appetite. Some LWS individuals are anorexic even when fed ad libitum with 2 to $20 \%$ not surviving the first weeks post hatch because they never start to eat [5]. HWS chicks are put on a food restriction programme at 56 days to avoid health issues associated with obesity. A neural involvement in the development of the phenotypes was implied by results after electrolytic lesions of the hypothalamus [6]. We recently compared gene expression in brain tissue using a global cDNA array analysis with the purpose to reveal over-all expression differences between the HWS and LWS lines that may be causally related to their extremely different phenotypes. The results showed that the long-term selection has produced minor but multiple expression differences in protein coding genes. Genes that regulate neuronal development and plasticity such as regulators of actin filament polymerization and genes involved in lipid metabolism were over-represented among differentially expressed genes [7].

The most differentially expressed transcripts were sequences with similarities to endogenous retroviral sequences (ERVs) that were identified as avian leucosis virus subgroup-E (ALVE). Brain tissue of LWS individuals contained higher levels of transcripts encoding ALVE than that of HWS individuals. These results attracted our interest because the occurrence and frequency of ALVE proviral integrations in different chicken breeds have been shown to be associated with altered physiology [8], disease resistance [9] and reproduction efficiency [10]. The ALVE integrations are transmitted in a Mendelian fashion [11] and ALVE proviral integration frequency can change in response to selection for specific traits [12-15]. These data suggest that differences in ALVE integration between the LWS and HWS lines indicated by the large difference in expression may be related to the establishment of the extreme phenotypes of these selected lines.

Periodic sampling of the selected lines and the establishment of an advanced intercross line allowed us to test if there was a link between the observed differential ALVE transcript levels and body weights. Moreover, we were able to determine if the different ALVE expression was transmitted by inheritance or by congenital infection. The extent of proviral integrations and their relation to levels of ALVE expression were also analysed. The results show that high ALVE expression among $\mathrm{F}_{9}$ birds was significantly correlated with low body weight for the females but not for males. The conserved correlation between high expression and low body weight after 9 generations of intercrosses, indicated that ALVE loci conferring high expression are genetically linked to or constitute in part the loci for a low body weight of the pullets.

\section{Materials and methods Animals and tissues}

Lines LWS and HWS were developed from a common founder population of crosses among seven inbred lines of White Plymouth Rocks, a breed used for egg production and broiler breeding. The selected lines have been maintained as closed populations by continuous selection for low or high body weight at 56 days of age for more than 45 generations. The average LWS and HWS chicks weigh $0.2 \mathrm{~kg}$ and $1.8 \mathrm{~kg}$ respectively at selection age. Descriptions of the selection programme and correlated responses of these lines are provided elsewhere $[5,16]$. All individuals sampled were from breeders of the same age, hatched on the same day, and provided feed and water ad libitum. Experimental procedures were approved by the Virginia Tech Institutional Animal Care and Use Committee. The founder lines as well as subsequent intercrosses were maintained at Virginia Polytechnic Institute and State University, Blacksburg, Virginia. The two lines have been kept in an identical and constant local environment during the course of selection. For example, each selected generation of the parental lines is hatched annually the first Tuesday in March and dietary formulation has remained constant throughout.

HWS and LWS chickens from generation 45 (G45, schematic outline of the generations Fig. 1A) were used for the cDNA array experiments and quantitative reverse transcription polymerase chain reaction (qRT-PCR) validation in peripheral as well as the brain tissues. Five or six males and five females from each line were sampled at hatch and at 56 days of age. Liver, pectoral muscle, adipose tissue and the brain region containing diencephalon, mesencephalon, pons, and medulla, were dissected on the day of hatch and at 56 days after hatch, immediately frozen in liquid nitrogen and stored at $-70^{\circ} \mathrm{C}$ until used.

Reciprocal cross $\mathrm{F}_{1}$ chickens from G46 of the parental lines were used to test inheritance of ALVE expression. The intercross population between HWS and LWS chickens was produced with the main purpose to identify genes explaining the large difference in body weight and growth 
A

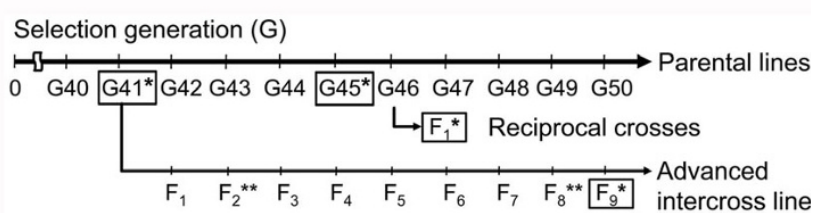

B

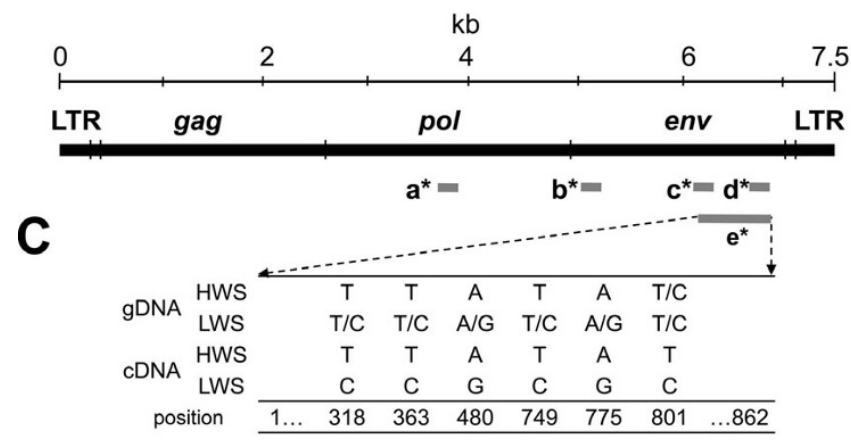

Figure I

Schematic ALV genome with PCR amplicons and

SNPs. A. Schematic time-line with parental generations and crosses. Generations in boxes were used for analyses in this study. Parental line generation (G) G4I* and G45* were used to examine number of ALVE integrations. Expression studies were performed in the brain and peripheral tissues of G45* birds. $\mathrm{F}_{1} *$ birds of the reciprocal crosses were utilized to test inheritance of ALVE genes. Eighty-two $\mathrm{F}_{9}{ }^{*}$ birds that form the advanced intercross were utilized for the correlation studies. QTL analyses have been performed with $\mathrm{F}_{2}{ }^{* *}$ and $\mathrm{F}_{8}{ }^{* *}$ birds in the advanced intercross line [16,53]. B. Black bar represents a complete ALVE proviral genome. Grey bars indicate PCR primers and amplicons. C. Six SNPs between HWS and LWS lines were found in the 862 bp PCR fragment $e^{*}$ from both genomic DNA and cDNA. $a^{*}$ : poll 97F/ pol269R. b*: Val_envF/Val_envR. c*: env277F/env353R. d*: qPCR_envF/qPCR_envR. $\mathrm{e}^{*}$ : an amplicon from a primer pair chENV232fwd/chENVI046rev. See table I.

between the parental lines [16]. This intercross was initiated from G41 of the parental lines (see Fig. 1A). Eight HWS males were mated to 22 LWS females and 8 LWS males were mated to $19 \mathrm{HWS}$ females to generate the $F_{1}$ generation. The number of animals in $F_{9}$ from the advanced intercross was 43 males and 43 females. Body weights at 56 days were recorded for all individuals. Livers were dissected for total RNA and genomic DNA preparation. Finally, 42 males and 38 females were used to measure relative mRNA amount of expressed ALVE with qRTPCR.

Genomic DNA was used to analyse proviral integration number from HWS and LWS lines in both G41 and G45, 10 White Leghorn (WL) and 10 Red Jungle Fowl (RJF).
The WL line (Line 13) originated from a Scandinavian selection and crossbreeding experiment [17] and was maintained at the Swedish University of Agricultural Sciences at a population size of 30 males and 30 females. The RJF birds originated from Thailand and were obtained from the Götala research station, Skara, Sweden. Information about the Line13 and RJF is published [18-20].

\section{Genomic DNA isolation}

Genomic DNA from the parental lines and $\mathrm{F}_{1}$ chickens were isolated from blood following standard genomic DNA isolation method [21]. DNA from $\mathrm{F}_{9}$ chickens was isolated from liver using automated nucleic acid purification using GeneMole (Mole Genetics, Oslo, Norway) according to the manufacturer's guide.

\section{Total RNA isolation and cDNA synthesis}

Each sample was homogenized into powder in presence of liquid nitrogen, followed by total RNA extraction with Trizol (Invitrogen Corporation, Carlsbad, CA, USA), and the quality of the total RNA was checked with the Agilent 2100 bioanalyser (Agilent Technologies, Santa Clara, CA, USA). One $\mu \mathrm{g}$ of total RNA was treated with RNase-free DNase (Promega Corporation, Madison, WI, USA) and used for cDNA synthesis with TaqMan Reverse Transcriptase reagents (Applied Biosystems, Foster City, CA, USA.) in a final volume of $50 \mu$ l containing $1 \times$ TaqMan RT buffer, $2.5 \mu \mathrm{M}$ random hexamers, $500 \mu \mathrm{M}$ of each dNTP, $5.5 \mathrm{mM} \mathrm{MgCl}_{2}, 20 \mathrm{U}$ RNase inhibitor, and $62.5 \mathrm{U}$ Multiscribe RTase. Samples were incubated for $10 \mathrm{~min}$ at $25^{\circ} \mathrm{C}, 30 \mathrm{~min}$ at $48^{\circ} \mathrm{C}$, and $5 \mathrm{~min}$ at $95^{\circ} \mathrm{C}$. The cDNA samples were stored at $-20^{\circ} \mathrm{C}$ for storage.

\section{Tumour Viral locus B (TVB) genotyping}

Genomic DNA samples of 10 HWS and 10 LWS birds (G41) were tested for genotyping of TVB alleles. A polymerase chain reaction-restriction fragment length polymorphism (PCR-RFLP) assay was performed following published procedures [22]. TVB genotypes were identified in 19 chickens, but the procedures failed to define a genotype for one LWS chicken.

\section{Cloning and sequencing of env fragments from CDNA and genomic DNA}

Primers to amplify part of the env gene were designed in non-variable regions of the proviral env gene after aligning a number of sequences from GenBank. A primer pair, chENV232fwd and chENV1046rev, were used to amplify an 862 bp fragment from genomic DNA as well as cDNA as templates. Genomic DNA from 47 HWS and LWS individuals (G41) was used to amplify and sequence the 862 bp env fragment. cDNA samples of one male and one female representing the G45 parental lines were pooled and used for sequencing. Furthermore, cDNA from $14 \mathrm{~F}_{9}$ chickens were sequenced. The PCR was performed in a 
total volume of $10 \mu \mathrm{l}$ containing about $50 \mathrm{ng}$ genomic DNA or cDNA, $1 \times$ PCR Buffer (Qiagen, Valencia, CA, USA), $2 \times$ Q solution (Qiagen), $1.5 \mathrm{mM} \mathrm{MgCl}_{2}$ (Qiagen), $200 \mu \mathrm{M}$ dNTP, 2 pmol of each primer and 0.5 U HotStarTaq Polymerase (Qiagen). Thermocycling started with 10 min at $94^{\circ} \mathrm{C}$, followed by touchdown PCR cycling with denaturation $30 \mathrm{sec}$ at $94^{\circ} \mathrm{C}$, annealing $30 \mathrm{sec}$ at $65^{\circ} \mathrm{C}$ and decreasing $1^{\circ} \mathrm{C}$ per cycle to $52^{\circ} \mathrm{C}$ and extension 1 $\min$ at $72^{\circ} \mathrm{C}$. Thirty five cycles were then performed with $30 \mathrm{sec}$ at $94^{\circ} \mathrm{C}, 30 \mathrm{sec}$ at $52^{\circ} \mathrm{C}$ and $1 \mathrm{~min}$ at $72^{\circ} \mathrm{C}$ and the program ended with $5 \mathrm{~min}$ at $72^{\circ} \mathrm{C}$. PCR products were separated in a $1 \%$ agarose gel and fragments excised and purified using QIAquick Gel Extraction Kit (Qiagen). PCR products generated from genomic DNA of parental lines and the expressed $e n v$ fragments of $\mathrm{F}_{9}$ chickens sequenced directly using the PCR primers to obtain a representative sequence. PCR fragments from cDNA of parental lines were all cloned into $\mathrm{pCR} / \mathrm{GW} / \mathrm{TOPO}$ vector using TOPO TA cloning kit (Invitrogen) prior to sequencing with the T7 and M13R universal primers. Sequences were controlled, aligned and compared using the Sequencher 3.1.1 program (Gene Codes Corporation, Ann Arbor, MI, USA).

\section{Relative quantitative Reverse Transcriptase-PCR (qRT- PCR)}

Two-step qRT-PCR was performed with the SYBR Green I Assay in combination with either ABI PRISM 7700 Sequence Detection System (Applied Biosystems), or MyiQ real-time PCR detection system (Bio-Rad Laboratories, Hercules, CA, USA) with iScript one-step RT-PCR kit with SYBR Green. One $\mu$ l of the cDNA, derived from $20 \mathrm{ng}$ of total RNA, was used as template in a $25 \mu \mathrm{l}$ reaction mixture. PCR reactions were carried out in duplicates with activation of the polymerase for $10 \mathrm{~min}$ at $95^{\circ} \mathrm{C}$ and 40 cycles of two PCR steps, $95^{\circ} \mathrm{C}$ for $15 \mathrm{sec}$ and $60^{\circ} \mathrm{C}$ for 60 sec. One-step qRT-PCR was used for analysis of env transcript levels in peripheral tissues of G45 and $F_{9}$ chickens. Twenty ng of total RNA was added in $25 \mu$ l of the reaction mixture and then incubated for $10 \mathrm{~min}$ at $50^{\circ} \mathrm{C}$ for cDNA synthesis, for $5 \mathrm{~min}$ at $95^{\circ} \mathrm{C}$ for RTase inactivation and 35 cycles of two steps with $10 \mathrm{sec}$ at $95^{\circ} \mathrm{C}$ and $30 \mathrm{sec}$ at $60^{\circ} \mathrm{C}$ to amplify target transcripts. Primers used in all quantita- tive PCR (see Fig. 1B) were designed with Primer Express 1.5 software (Applied Biosystems) and are listed in table 1. A primer pair for quantitative PCR experiments, qPCR_envF and qPCR_envR, was designed within 862 bp of the PCR product described above. Chicken $\beta$-actin (GeneBank accession No. NM 205518) and glyceraldehyde-3-phosphate dehydrogenase (GAPDH, GeneBank accession No. NM 204305) were used as references. Each sample was assigned a CT (threshold cycle) value corresponding to the PCR cycle at which fluorescent emission, detected real time, reached a threshold above baseline. PCR products were separated in agarose gel to confirm that the products had the expected size. Collected data were normalized against the reference gene $\mathrm{Ct}$ values. Subsequently, relative mRNA expression levels of the test genes were determined in comparison with calibrators; for example, average expression levels of 0 day-old HWS males or shared subjects over the PCR plates. To examine whether the expression levels in HWS and LWS chickens were significantly different, one-way ANOVA together with Newman-Keuls post-hoc test in GraphPad Prism 3.03 (GraphPad Software, San Diego, California, USA) was utilized.

\section{Analysis of proviral integration in genomic DNA}

The extent of proviral integration of ALVE was estimated by measuring the env proviral gene with qPCR in genomic DNA. The qPCR was performed as the qRT-PCR but with genomic DNA as template. Exactly $20 \mathrm{ng}$ of the genomic DNA was analysed with primers qPCR_envF and qPCR_envR using a protocol with activation of the polymerase for $10 \mathrm{~min}$ at $95^{\circ} \mathrm{C}$ and 40 cycles of two PCR steps, for $15 \mathrm{sec}$ at $95^{\circ} \mathrm{C}$ and for $60 \mathrm{sec}$ at $60^{\circ} \mathrm{C}$. Primers for chicken pro-opiomelanocortin (POMC, GeneBank accession NM 001031098) and pre-melanin-concentrating hormone (PMCH, GeneBank accession NW 001471513) were included in each of PCR plates as representatives for single-copy genes. All env $\mathrm{Ct}$ values were then normalized to the average of the POMC and PMCH Ct values and the relative env copy numbers were adjusted to the standard curve to get the env integration copy-number per haploid genome.

Table I: List of the genes and primer pairs used for qPCR and qRT-PCR experiments

\begin{tabular}{llll}
\hline Primer names forward/revers & Amplicon in figure IA & Forward & Reverse \\
\hline Beta-actinF/Beta-actinR & - & AGGTCATCACCATTGGCAATG & CCCAAGAAAGATGGCTGGAA \\
GAPDHF/GAPDHR & - & GGGAAGCTTACTGGAATGGCT & GGCAGGTCAGGTCAACAACA \\
POMCF/POMCR & - & GCTACGGCGGCTTCATGA & CGATGGCGTTTTTGACAGAG \\
PMCHF/PMCHR & - & CGAAATGGAGACGGAACTGAA & CATCCAAGAAGCTTTCCTCAATCT \\
Val_envF/Val_envR & $\mathrm{b}^{*}$ & ACCCGGACATCACCCAAAG & AGTCAGAAATGCCTGCAAAAAGA \\
chENV232fwd/chENVI046rev & $\mathrm{e}^{*}$ & ACGGATTTCTGCCTCTCTACACA & TTCCTTGCCATGCGCGATCCC \\
qPCR_envF/qPCR_envR & $\mathrm{d}^{*}$ & GAAACTACCTTGTGTGCTGTCG & CGGATGTTGTGGAAAAACGA \\
env277F/env353R & $\mathrm{c}^{*}$ & CCCAAAATCTGTAGCCATATGC & TACGGTGGTGACAGCGGATAGG \\
polli97F/pol269R & $\mathrm{a}^{*}$ & TGCTTGTCTCCCCAGGGTAT & GGTGACTAAGAAAGATGAGGCGA
\end{tabular}


A plasmid (3679 bp) that contained the 862 bp env PCR product in $\mathrm{pCR} / \mathrm{GW} / \mathrm{TOPO}$ vector was used to make a standard curve. The plasmid was diluted serially in 2-fold, ranging from $0.02 \mathrm{ng}$ to $0.16 \mathrm{pg}$ per reaction volume in 8 dilutions, then qPCR was run together with qPCR_env primers and Ct values recorded. The number of the envplasmids in each reaction was calculated. $n$; plasmid length (bp), $M$; average molecular weight of a base pair $(650 \mathrm{~g} / \mathrm{mol}), N_{\mathrm{A}}$ is Avogadro's constant, $m$; mass of the DNA.

$$
\text { Copy number of env plasmid }=m /\left((n \times M) / N_{\mathrm{A}}\right)
$$

A standard curve was plotted using the plasmid number and the corresponding $\mathrm{Ct}$ values $\left(2^{-\mathrm{Ct}}\right)$. A linear relationship was examined $\left(y=10^{11 *} \mathrm{x}, \mathrm{R}^{2}=0.9927\right)$. The number of haploid chicken genomes in $20 \mathrm{ng}$ was also calculated using the chicken genome size $n=1.05 \times 10^{9} \mathrm{bp}$. There are
17650 haploid genome copies per 20 ng genomic DNA. The env gene integration number per genome for each individual was calculated using $\left(10^{11 *} 2^{-\mathrm{Ct}}\right) / 17650$.

\section{Results}

\section{High ALVE expression in the LWS line}

The differential expression of ALV-related sequences between lines LWS and HWS (G45) was found using a cDNA microarray analysis [7]. Brain tissue from both hatchlings and 56 day-old individuals of both sexes were analysed, and among the differentially expressed transcripts, at least 10 endogenous retrovirus-related transcripts were differentially expressed $(\mathrm{p}<0.001)$ with high levels in the LWS line (Table 2, [23,24]). BLAST-search results using the array sequences revealed similarities to endogenous ALVE retrovirus elements. The fold difference between HWS and LWS lines varied from 2 to $>30$-fold (Table 2).

Table 2: Differentially expressed virus-related sequence from cDNA microarray analysis

\begin{tabular}{|c|c|c|c|c|c|c|c|c|c|}
\hline \multirow[t]{2}{*}{ Probe ID } & \multirow[t]{2}{*}{ GeneBank ID } & \multirow{2}{*}{$\begin{array}{l}\text { Gene annotation } \\
\text { from the best } \\
\text { hit/Domain }\end{array}$} & \multicolumn{4}{|c|}{ Fold difference of array expression (LWS/HWS) } & \multicolumn{3}{|c|}{ Nucleotide BLAST } \\
\hline & & & $0 \mathrm{~d}$ male & $0 \mathrm{~d}$ female & $56 \mathrm{~d}$ male & $56 \mathrm{~d}$ female & $\begin{array}{l}\text { EST } \\
\text { length }\end{array}$ & $\begin{array}{l}\text { Hit length } \\
\text { (hit/total) }\end{array}$ & $\begin{array}{l}\text { Similarity } \\
\text { (\%) }\end{array}$ \\
\hline RJA064AII.abI & CN220264 & $\begin{array}{l}\text { ALV ev- } 2 I \text { and } \\
\text { its integration } \\
\text { site }\end{array}$ & 30.8 & 20.6 & 23.8 & 21.5 & 377 & $305 / 2734$ & 97.7 \\
\hline RDA-8I & NA & $\begin{array}{l}\text { ALV ADOL- } \\
7501 \text {, proviral } \\
\text { sequence }\end{array}$ & 20.0 & 12.9 & 10.4 & 11.2 & 210 & $207 / 7612$ & 96.2 \\
\hline RJA002E06 & CN216922 & $\begin{array}{l}\text { ALV strain ev-3/ } \\
\text { Avian gp } 85\end{array}$ & 18.4 & 13.6 & 14.6 & 14.4 & 757 & $757 / 5842$ & 99.1 \\
\hline WLA044E07.abI & $\underline{\mathrm{CN} 223892}$ & $\begin{array}{l}\text { ALV strain ev-3, } \\
\text { complete } \\
\text { genome }\end{array}$ & 8.3 & 5.7 & 6.8 & 6.2 & 588 & $409 / 5842$ & 100 \\
\hline WLA070B07.ab I & CN230959 & $\begin{array}{l}\text { ALV strain ev-3, } \\
\text { complete } \\
\text { genome }\end{array}$ & 6.9 & 4.9 & 7.8 & 6.9 & 368 & $153 / 5842$ & 100 \\
\hline VeFi2.66.C3* & $\mathrm{CN} 221614$ & $\begin{array}{l}\text { Myeloblastosis- } \\
\text { assoc. virus } \\
\text { genes/Avian } \\
\text { gp85 }\end{array}$ & 2.0 & 1.9 & 2.0 & 1.9 & 2567 & $2120 / 7704$ & 92.3 \\
\hline WLA097G09.ab I & CN234473 & $\begin{array}{l}\text { ALV (strain RAV } \\
\text { 7) } 3^{\prime} \text { noncoding } \\
\text { region }\end{array}$ & 2.5 & 2.3 & - & 2.1 & 326 & $274 / 358$ & 94.5 \\
\hline WLA043CI2.ab I & CN222802 & $\begin{array}{l}\text { ALV strain ev-3, } \\
\text { complete } \\
\text { genome }\end{array}$ & 1.6 & - & 1.6 & 1.6 & 454 & $451 / 5842$ & 96.3 \\
\hline WLA0I9C03.abI & CN220591 & $\begin{array}{l}\text { ALV strain ev-6 } \\
\text { envelope } \\
\text { polyprotein }\end{array}$ & - & 4.3 & 4.8 & 4.8 & 685 & $151 / 2720$ & 96.7 \\
\hline RDA-69 & NA & $\begin{array}{l}\text { ALV strain ev-I, } \\
\text { complete } \\
\text { genome }\end{array}$ & - & - & - & 2.5 & 185 & $170 / 7525$ & 98.2 \\
\hline
\end{tabular}

The gene annotation and BLAST result was collected from http://www.sbc.su.se/ arve/chicken[23,24]. NA, GeneBank ID is not available. VeFi2.66.C3* had the best hit in Myeloblastosis-associated virus genes, however, BLAST result with protein sequences from SwissProt and TrEMBL showed the best hit on env protein of ALV. 
Twenty-three virus-related sequences were arbitrarily selected from the array transcript list: nine ALV-related sequences, five other avian retrovirus-related sequences, (including Rous sarcoma virus transcription enhancer factor II, env gene of Rous sarcoma virus and gag/pol polyprotein of avian myeloblastosis virus), and nine retrovirus-related sequences from other species. Only the ALVE-related sequences were differentially expressed (data not shown).

Primers for qRT-PCR were designed against the env gene region in the most differentially expressed sequence CN220264 (primer b*, Table 1, Fig. 1B). Five or 6 individuals from each age and sex were analyzed to confirm the differential levels. The ALVE expression in HWS chickens was notably homogenous at a very low level at both ages and for both sexes, while LWS chickens expressed high ALVE levels with individual variation (Fig. 2A).

We tested whether the high ALVE levels were specific to LWS brain tissue. Peripheral tissues from HWS and LWS 56 days-old chickens (G45) were analysed and high ALVE mRNA levels were found in all brain, liver, pectoral muscle and adipose tissues analyzed (Fig. 2B).

\section{Genetic transmission}

Although transmission of an endogenous retrovirus from one generation to another is generally regarded as genetic,

\section{A}

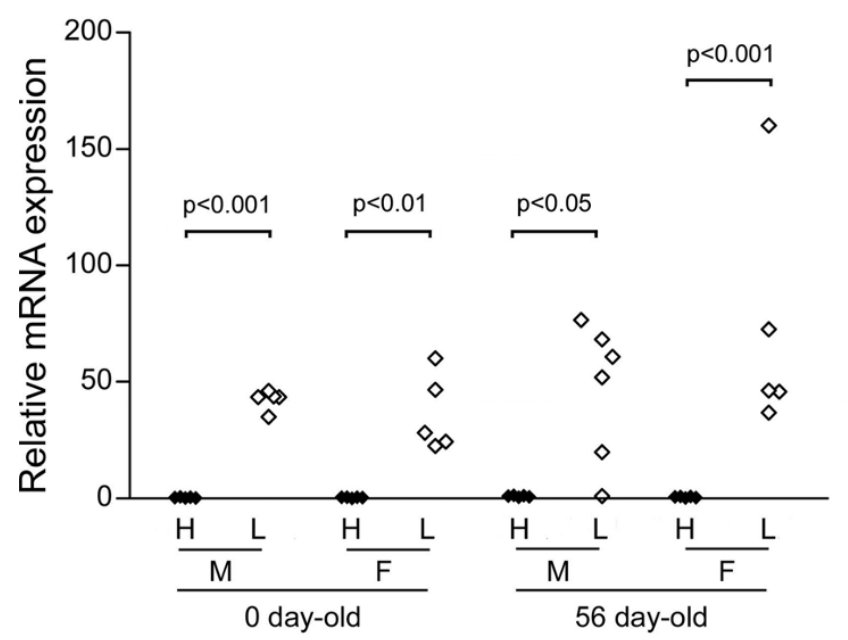

intact transcribed ALVE provirus has been transmitted by congenital infection [25-27]. To assess if the high ALVE expression was transmitted by congenital infection or inherited, we analyzed ALVE levels in $\mathrm{F}_{1}$ individuals from reciprocal HWS $\times$ LWS crosses (G46). In case of congenital infection from hen to egg, high expression in $\mathrm{F}_{1}$ progenies should come from crosses between LWS dams and HWS sires. In case of genetic transmission of the high ALVE levels, the $\mathrm{F}_{1}$ individuals would have higher levels independent of whether the dams or sires were from LWS line. Furthermore, a wide range of ALVE expression levels from the low level in HWS to the high levels found in LWS individuals should be observed in the $\mathrm{F}_{1}$ generation. Quantitative RT-PCR was performed with primers against three different regions of the proviral ALVE transcript (Fig. 1B). We found that some $\mathrm{F}_{1}$ individuals from LWS dams had low levels, while their siblings from the same LWS dams had high ALVE levels. LWS sires produced progeny with high and low ALVE levels (Fig. 3). $\mathrm{F}_{1}$ chickens from each reciprocal crosses had a full range of expression levels (Fig. 3 ). The results strongly suggest that the high ALVE expression in LWS chickens are genetically determined and not transmitted by congenital infection.

\section{The parental lines are susceptible to ALV infection}

Chickens may be susceptible or resistant to certain ALV retroviruses depending on the specific virus adherence allele they have in the Tumour Viral locus B (TVB) [28].

\section{B}

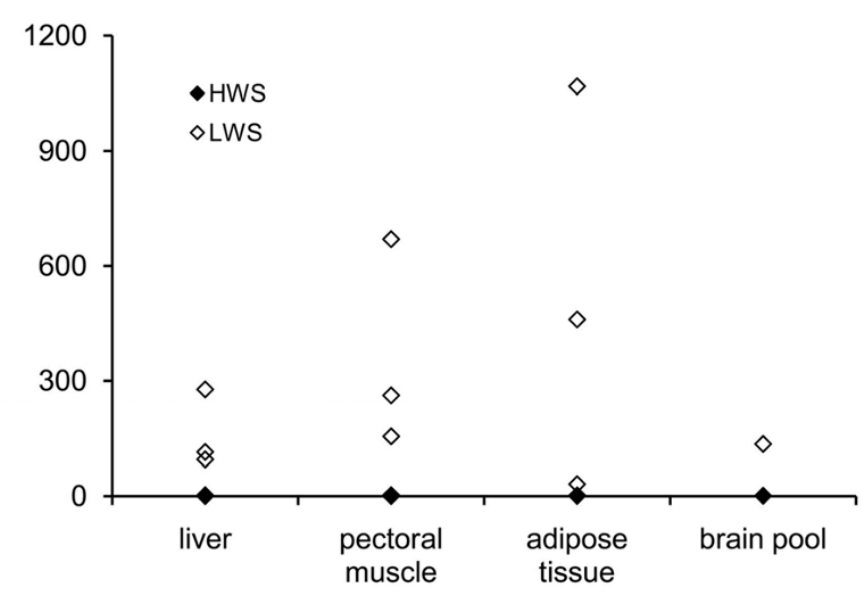

\section{Figure 2}

Differential expression of ALVE in brain and peripheral tissues of HWS and LWS chickens. Relative mRNA expression levels of env gene were measured using qRT-PCR with a primer pair b* shown in table I and figure IB. A. Validation of differential expression of ALVE genes in CDNA microarray experiment. One-way ANOVA together with Newman-Keuls test as a post-hoc analysis was utilized. B. ALVE expression in peripheral tissues of HWS and LWS lines. Peripheral tissues were dissected from chickens on day 56 and the brain from chicks at hatch. $\mathrm{N}=3$ for each of HWS and LWS lines in all peripheral tissues and cDNA samples from five birds were pooled for the brain pools. H, HWS; L, LWS; M, males; F, females. 

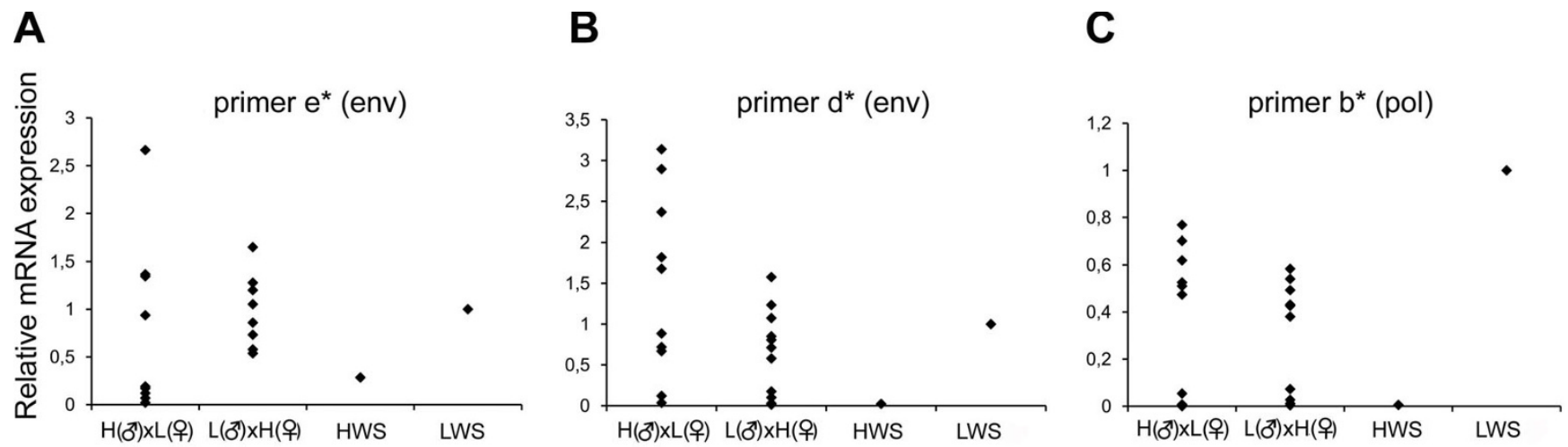

\section{Figure 3}

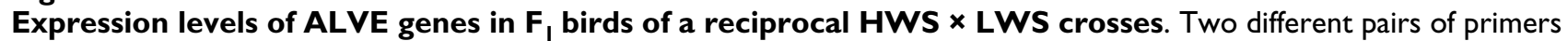
were designed against env ( $\mathbf{A}$ and $\mathbf{B}$, primer pairs $\mathrm{c}^{*}$ and $\mathrm{d}^{*}$ in table $\mathrm{I}$ and figure $\left.5 \mathrm{C}\right)$ and one against pol (C, primer $\left.\mathrm{a}^{*}\right)$ in the ALVE genome. $H\left(\sigma^{7}\right) \times L(\$)$ represents $F_{1}$ birds from HWS sires and LWS dams, and $F_{1}$ birds in $L\left(O^{7}\right) \times H(Q)$ are from $L W S$ sires and HWS dams. $\mathrm{N}=10$ in $\mathrm{H}\left(\sigma^{7}\right) \times \mathrm{L}(q)$ and $\mathrm{N}=\mathrm{II}$ in $\mathrm{L}\left(\sigma^{7}\right) \times \mathrm{H}(q)$.

The TVB locus encodes a tumour necrosis factor receptor that interacts with the Env glycoprotein and is required for the viral entry into cells $[29,30]$. The $T V B * S 1$ allele allows entry of ALV subgroups B, D and ALVE, while TVB*S3 permits viral entry of subgroup $B$ and $D$ but not $E$. The TVB* $R$ allele produces truncated receptors that do not allow entry of any ALV [31,32]. Resistance to retrovirus entry could

A

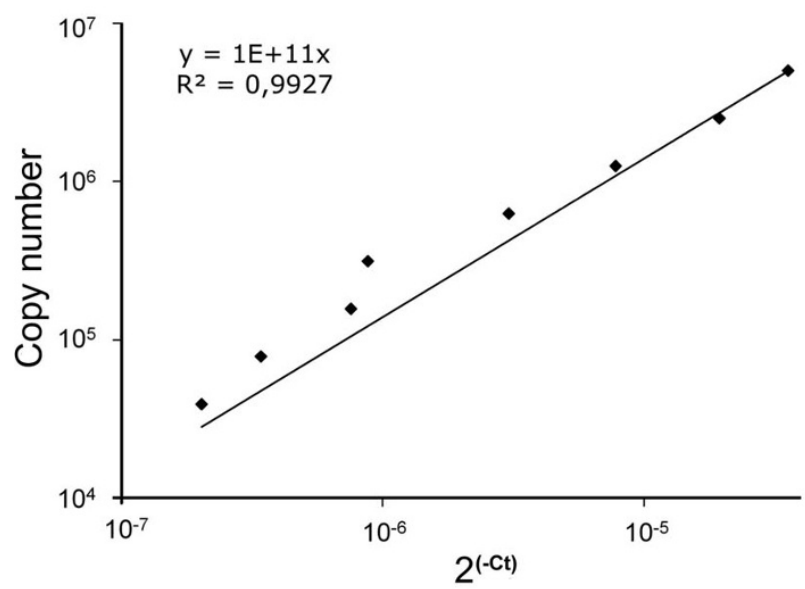

influence ALVE expression and be associated with selection for body weight. We tentatively hypothesized that the HWS line could be resistant and the LWS susceptible to ALVE. Ten HWS and 10 LWS (G41) individuals were typed for the TVB allele [22]. All successfully tested 19 parental individuals were positive for the $T V B^{*} \mathrm{~S} 1$ allele that is susceptible for ALVE infection. One sample could

B

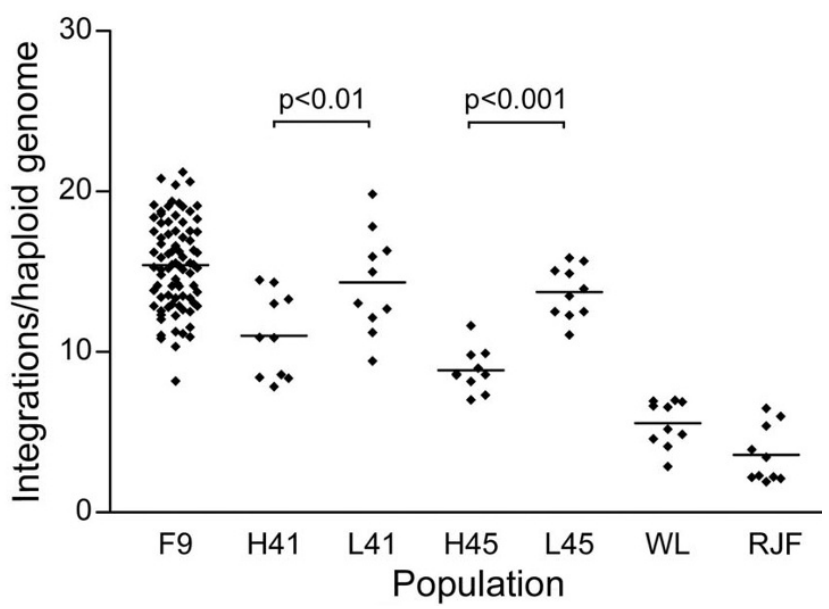

Figure 4

Determination of the number of proviral integrations in different chicken populations. A. Standard curve based on diluted plasmid with a PCR product. B. Relative copy numbers of env gene were examined by qPCR with primer $d^{*}$ and the numbers of integration per haploid genome were determined using the standard curve shown in $\mathbf{A}$. Horizontal bars represent mean values of integration number for each population. One-way ANOVA together with Newman-Keuls test as a post-hoc analysis was utilized. Mean \pm SEM: F9 $=I 5.42 \pm 0.3 \mathrm{I}, \mathrm{H} 4 \mathrm{I}=\mathrm{II} .0 \mathrm{I} \pm 0.83, \mathrm{~L} 4 \mathrm{I}=\mathrm{I} 4.34 \pm \mathrm{I} .0 \mathrm{I}, \mathrm{H} 45=8.87 \pm 0.42, \mathrm{~L} 45=\mathrm{I} 3.73$ $\pm 0.5 \mathrm{I}, \mathrm{WL}=5.56 \pm 0.46$ and $\mathrm{RJ}=3.59 \pm 0.56 . \mathrm{N}=82$ in $\mathrm{F}_{9}$ birds and $\mathrm{n}=10$ in the other populations. F9, generation 9 of the advanced intercross line; H4I and L4I, generation 4I of the HWS and LWS lines, respectively; H45 and L45, generation 45 of the parental lines; WL, White Leghorn and RJF, Red Jungle Fowl. 
not be genotyped. The tentative hypothesis was rejected and it was concluded that the lines were equally susceptible.

\section{Number of proviral ALVE integrations}

A central hypothesis in this work was that difference in ALVE expression levels between lines could directly contribute to the genetic differences in growth between the HWS and LWS lines. The first question was then if the number of proviral integrations differed between the lines. Therefore, we analysed the extent of proviral integration by using qPCR and by analyzing the ALVE env gene content in genomic DNA. In addition to the parental lines (G41 and G45), we also analysed individuals from the $\mathrm{F}_{9}$ intercross and individuals from WL (line13) and RJF. First, a standard curve with a plasmid containing an env gene PCR product was made and used as an external standard for qPCR analysis (Fig. 4A). The initial result revealed that three initially selected RJF individuals had 2 to 3.5 env gene copies per haploid genome. This result was compared to a BLAST search of the RJF genome database (Assembly May-06) using the env primer sequences. Three perfect hits were found for the primer sequences; and we concluded that the qPCR analysis provided adequate results. Eighty-two $\mathrm{F}_{9}, 40$ from each HWS and LWS line (20 G41 and 20 G45), 10 RJFs and 10 WLHs were then analysed. The WLs and RJFs had 2 to 7 integrations, with 7 to 15 in HWS, and 9 to 20 in LWS. The difference between HWS and LWS lines was significant at both generations tested (G41 and G45). The integration numbers in individuals from each line from the two generations were not significantly different even though it was evident that G41 had a larger variance than G45 in particularly among the LWS individuals (Fig. 4B). The number of integrations in the $\mathrm{F}_{9}$ ranged from 8 to 22 (Fig. $4 \mathrm{~B}$ ). It is worth noting that this variance was similar in the $\mathrm{F}_{9}$ cross as in their parental generation (G41). A schematic outline of the parental and intercross generations is shown in Fig. $1 \mathrm{~A}$.

\section{Number of integrations in relation to ALVE expression and growth patterns}

The observation that the LWS chickens had more integrations and higher expression than the HWS chickens, led us to the question if the number of proviral integrations additively contributed to the different expression levels. Such association was addressed using the results from the $\mathrm{F}_{9}$ chickens. A correlation of $0.28(\mathrm{p}<0.04)$ was obtained between number and expression when all $F_{9}$ chickens were analyzed (Fig. 5A), suggesting that not all, but a few different ALVE integrations contributed to the higher expression levels in LWS.

A weak negative correlation between number of integrations and body weight for all of the $\mathrm{F}_{9}$ individuals was found but the trend was not statistically significant Fig. $5 \mathrm{~B}$. This result showed that individuals with many ALVE proviral integrations, overall did not have lower body weights (Fig. 5B) but this does not exclude the possibility that the presence of some specific integrations has a direct effect on body weight.

Next we plotted the body weight of the $\mathrm{F}_{9}$ individuals against the ALVE expression levels and calculated the correlation. The expression was measured with qRT-PCR using primers in the env gene (primer $\mathrm{d}^{*}$ ) with total RNA extracted from liver. The negative correlation (-0.49) between ALVE expression and body weight was highly significant for females ( $\mathrm{p}<0.01$, Fig. 5D) but not for males (Fig. 5C).

\section{Env sequence polymorphisms in genomic and expressed sequences}

We PCR-amplified and sequenced an 862 bp env fragment from genomic and cDNA from the two parental lines. The env gene is known to have the highest degree of polymorphisms in the proviral genome. The sequences obtained from genomic DNA from 21 HWS and 22 LWS individuals were polymorphic at six single base pair positions: 318, 363, 480, 749, 775 and 801 bp (Fig. 1C). The sequence result illustrated that there were fixed HWS and LWS line-specific SNPs; the HWS-variants and a LWS-variant. The HWS line had only the HWS-variants while the LWS line had all variants. The cDNA sequences revealed that the high expression levels found in LWS line constituted the LWS variant and the low expression levels in HWS individuals constituted the HWS-variant.

The env fragment was also amplified and sequenced from cDNA from $24 \mathrm{~F}_{9}$ chickens (13 males and 11 females) with high or low expression, eleven with high env expression and 13 with low env expression. The individuals are indicated in Fig. 5C and 5D. All 11 individuals with high ALVE expression and 6 individuals with lower expression had the LWS-variant of the DNA sequence. The 7 chickens with the HWS-variant were among the ones with lowest env expression. Six were males and only one female.

\section{Discussion}

In this study we pursued the observation that high expression of an endogenous retrovirus of the ALVE type was associated with low growth in one of two chicken lines established by long term divergent selection for high or low body weight $[5,7]$. We conclude that the high levels in the LWS line show Mendelian inheritance. LWS birds have more ALVE integrations than HWS birds, which in turn have a larger number of integrations compared with WL and RJF chickens. Using $\mathrm{F}_{9}$ birds from an advanced intercross between the two selected lines we tested if there was a correlation between body weight, ALVE integrations and 
A

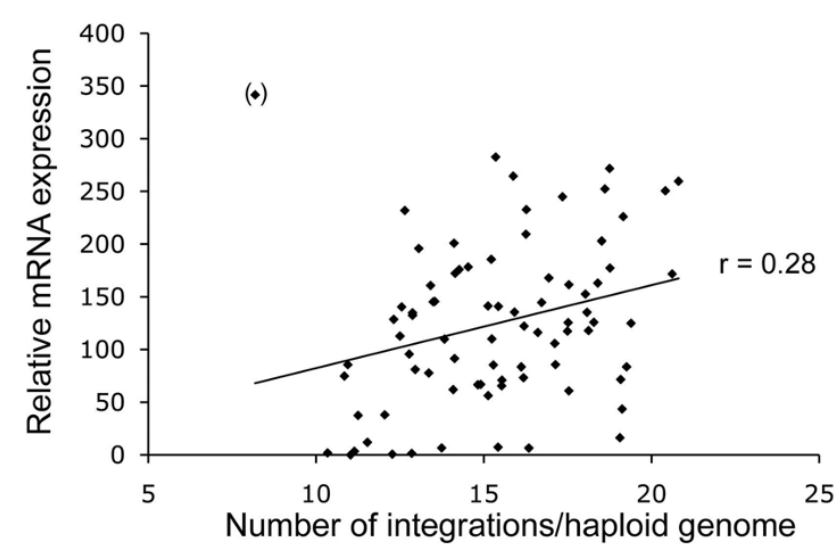

C

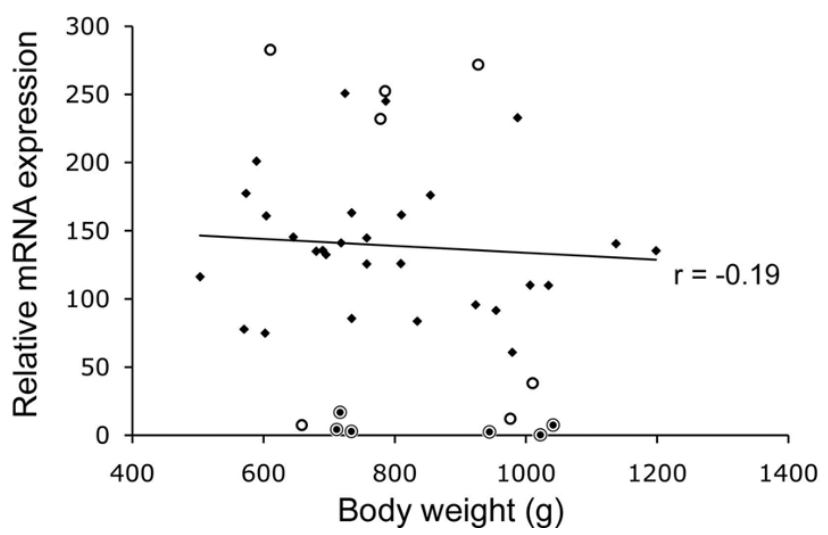

B

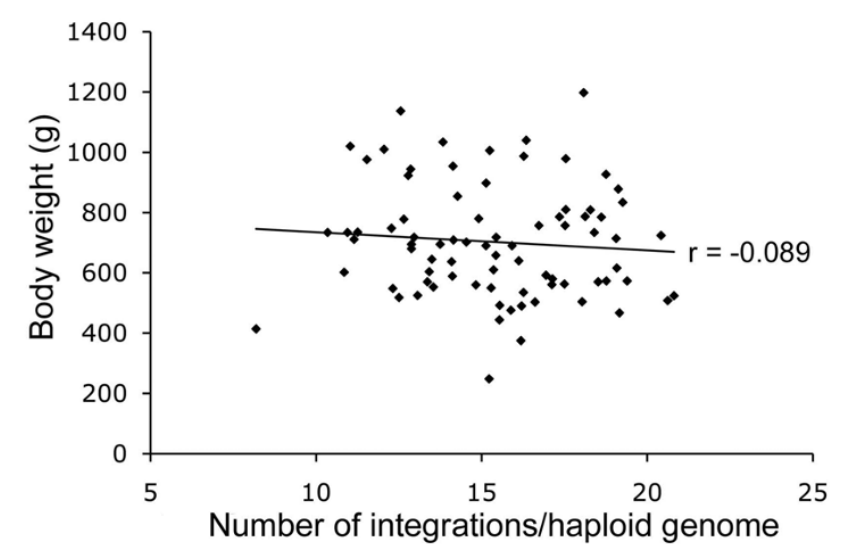

D

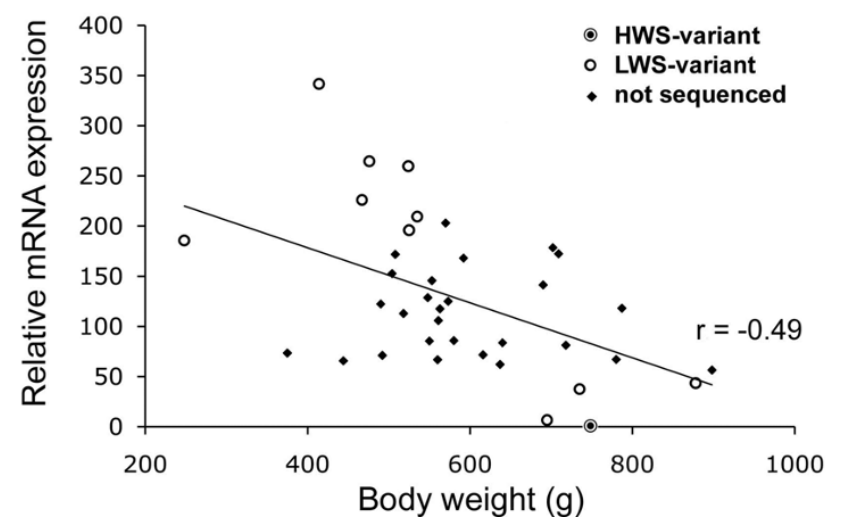

Figure 5

Correlation between number-of-integrations, ALVE mRNA expression levels and body weight in $F_{9}$ birds from the advanced intercross line. Each dot in the plots represents an individual of $F_{9}$ generation. A. Plot based on mRNA expression levels against ALVE integration number in $80 \mathrm{~F}_{9}$ birds. $P<0.05$ for correlation coefficient $r=0.28$ including all points as shown in panel A. $P<0.00$ I for correlation coefficient $r=0.4$ I when one deviating data point (black diamond) was omitted from the analysis. B. Plot based on body weight against the number of ALVE integration in $80 F_{9}$ birds. $P<0.5$ for correlation coefficient. $\mathbf{C}$ and $\mathbf{D}$. Correlation between the body weight and the ALVE expression in $\mathrm{F}_{9}$ birds from the advanced intercross line. Open-circled data points indicate individuals of which env cDNA fragments (amplicon $e^{*}$ in figure IC) were sequenced in order to find out sequence variant. C. Plot based on $42 F_{9}$ male chickens. $P<0.22$ for the correlation coefficient. D. Plot based on $38 \mathrm{~F}_{9}$ female chickens. $\mathrm{P}<0.0 \mathrm{l}$ for the correlation coefficient. H, HWS-variant; L, LWS-variant.

expression levels. The results indicated that a minority of the integrations contributed to the higher levels and that high expression was significantly correlated to lower body weights of females but not males. The conserved correlation between high ALVE expression and low body weight in females after 9 generations of intercrosses indicates that ALVE loci conferring high expression are genetically linked to or constitute loci directly contributing to low body weight of LWS chickens in a sex-limited fashion.
The chicken genome contains four families of ERV elements classified as chicken repeat 1 (CR1) elements, ALVEs, avian retrotransposones from the chicken genome (ART-CHs) and endogenous avian retrovirus elements (EAV-0) [8]. Although the microarray contained probes with different retroviral sequences, only ALVE-related sequences were identified as differentially expressed. The env gene in the ALVE proviral genome is a source for genetic diversity through recombination with exogenous 
viruses [33,34]. The sequence diversity of this gene constitutes the basis for defining the six subgroups of $\operatorname{ALV}(\mathrm{A}, \mathrm{B}$, $\mathrm{C}, \mathrm{D}, \mathrm{E}, \mathrm{J})$ and is related to variation in infection susceptibility, receptor interference as well as antibody neutralization [8]. The env gene was used as target for the primer design for qPCR, qRT-PCR and for sequencing. The primers we used amplified the endogenous $e v$-loci of several ALVE subtypes, but did not match other types of retrovirus such as RSV or avian myeloblastosis virus. Primers against the ALVE pol gene confirmed the differential expression seen with the env primers (Fig. 3C).

Endogenous retrovirus elements are in most cases transmitted genetically [35]. Transmission of ALV can occur via several natural routes [11]. Exogenous ALVs are transmitted horizontally by infection between individuals or vertically from hen to progeny in ovo by congenital transmission [11,36]. Horizontal transmission is relatively inefficient while congenital transmission is very efficient and leads to a high ratio of infected embryos [8]. The ALVE elements exist in the chicken genome as partial or complete ALVE proviral genomes. Endogenous elements have in general a limited or restricted ability to transmit virus congenitally, in contrast to exogenous ALV that undergo highly efficient congenital transmission $[37,38]$. However, it was demonstrated that some $e v$-loci that encode complete provirus genomes, particularly $e v-12$ and $e v-21$, can be transmitted at higher frequencies from subgroup E susceptible dams to susceptible progeny [2527].

Susceptibility of chickens to ALV retroviral infection is regulated by subtype-specific cell membrane receptors that interact with the Env glycoprotein. Exogenous ALV subtypes B and D, and virus particles of endogenous ALVE infect through this interaction. Different types of receptors for ALV subtypes B, D and E are encoded by three alleles of the TVB locus. The TVB*S1 allele encodes tumour necrosis factor receptors that are required for the viral entry of all three subgroups while TVB*S3 permits viral entry of subgroup $\mathrm{B}$ and $\mathrm{D}$ but not $\mathrm{E}$. The TVB* $\mathrm{R}$ allele produces truncated receptors that do not support entry of any ALV $[28,31,32]$. All of the successfully tested 19 individuals (G41) possessed the TVB*S1 allele that gives susceptibility for ALVE. This result is in agreement with that $83 \%$ of chickens from 36 broiler lines were homozygous for TVB*S1 [39]. Hence, both HWS and LWS chickens are susceptible for ALVE infection and polymorphism in the $T V B$ locus is neither a result of the long term selection nor is it likely to be involved in the high ALVE expressing phenotype.

The possibility that the LWS chickens propagated high ALVE expression via congenital infection from hen to egg was examined. We analyzed ALVE expression in an $\mathrm{F}_{1}$ gen- eration after a reciprocal cross between the lines (G46). $F_{1}$ siblings from the same LWS dam often had both high and low ALVE levels and LWS males transmitted high expression to their progeny (Fig. 3). Moreover, hens with high ALVE expression did not always transmit high expression to their progeny as would have been expected by congenital infection. Rather, their expression spanned the full range of expression levels seen in the parentals. Therefore, the high/low ALVE expression levels were likely to have been inherited and these data support a Mendelian mode of genetic transmission of ALVE expression. Furthermore, an exogenous ALV infection among parental LWS is less plausible because ALV-related disease symptoms have not been observed during the course of selection [5]. It cannot be excluded that such infection has occurred and by recombination may have formed elements that triggered increased ALVE expression because there are examples of male-mediated congenital transmission of ALVE [40]. The active transcription of ALVE in the tested tissues may also have introduced recombinant somatic ALVE pro-viral integrations [34].

The number of env gene integrations in RJF and WLs ranged from 2 to 7 per haploid genome. Both the HWS and LWS lines had more integrations than RJF and WLs. HWS individuals had significantly fewer integrations than LWS while the $\mathrm{F}_{9}$ birds had 8 to 22 env integrations per haploid genome, a number similar to that for the LWS line (Fig. 4B). The reported average for layer chickens is 1 to 3 elements, while that for meat-type chickens is 6 to 10 [15]. Altogether 22 different ALVE loci have been identified in WLs and current estimates suggest that there may be over 50 different loci [41]. Although the number of ALVE integrations in the genome pool of the White Plymouth Rock founder population for the selection experiment is not known, they probably had a similar number of $e v$-loci as the HWS and LWS lines (7 to 22 integrations). This number is little higher than the average meat bird, however, the GPCR in this study may be more sensitive than previously used methods.

HWS birds have low ALVE expression and fewer ALVE integrations than LWS birds suggesting that differential selection for growth has influenced both ALVE expression and integration number (Figs. 2 and 5). This hypothesis was supported by results from the $F_{9}$ population where we observed a weak but significant correlation between integration number and expression (Fig. 5A). The results suggested that only a few of the integrations contributed to the high levels of expression. This assumption was further supported by the occurrence of sequence polymorphism for the env gene (Fig. 1C), and one sequence variant was exclusively found in LWS birds. Only this LWS-variant was found in CDNA from LWS birds and $\mathrm{F}_{9}$ individuals with high ALVE expression (Figs. 5C, D and 1C). In contrast, in 
genomic DNA from LWS chicken both the LWS- and HWS-variants were present and the HWS variant was more frequent. Thus, while LWS-variant integrations are fewer than the HWS-variant they contributed more to the high levels of expression in LWS individuals and certain $\mathrm{F}_{9}$ birds. An obvious interpretation is that selection for high body weight has been effective to purge or silence high expressing ALVE loci. Another possible explanation is that a previous ongoing infection would have produced novel integrations that led to the increased levels in the LWS line. For this to occur would require novel integration in the germ line in order to transmit to the next generations.

Our data from the $\mathrm{F}_{9}$ generation suggest that the actively expressed ALVE loci are causing reduced growth and that this effect is more pronounced in the females than in males. This pattern may be explained by a sex-specific response or because the effects by high ALVE expression are more penetrant for smaller birds and pullets are overall smaller than males. ALVE integration is of interest for the poultry industry because the frequency of integration alters the responses to selection for economical traits $[9,10,12-15]$. The mechanism may be that integrations directly or indirectly disrupt other genes $[8,42]$. However, in humans there are only rare examples where a recessive monogenic disorder is caused by HERV integration disrupting gene function. Alternatively, a high virus expression load such as in the LWS line may affect the growth indirectly. The activation of inflammatory cytokines such as the interferon-gamma, TNF-alpha, interleukin-1 and -6, their receptors and signalling pathway components are signatures of retrovirus infection $[43,44]$. Such genes were not over-represented in the cDNA array analysis results [7]. Factors that regulate retrovirus trans-cellular transport and budding are also regulated at high virus loads such as actin-related modulators including Rho-like factors and trans-golgi factors [44]. Similar activation patterns have been seen after avian RSV infection of chick fibroblasts [45]. The budding of enveloped RNA viruses, including HIV and other retroviruses, usurp a cellular pathway that is normally used to form vesicles and transport them into multi-vesicular bodies [46]. Some of the differentially expressed genes observed in our previous study [7] while associated with alterations in neuronal plasticity are also regulated during acute and chronic retrovirus infections $[45,47]$. These include vesicle trafficking systems such as the ARL/ARF factors and FKBP5 as well as the Nephroblastoma overexpressed gene (Nov). Nov was reported to decrease in fibroblasts after Rous sarcoma virus transformation [45] and we observed lower Nov expression in LWS chicken than in HWS chickens. Nov was initially identified as a cellular gene in chick nephroblastomas induced by the retrovirus myeloblastosis-associated virus [48]. The identification of Nov as being differentially expressed between lines indicates that the expressed endogenous ALVE sequences may influence cellular gene expression and may therefore contribute to the selection response for growth.

Both HWS and LWS pullets showed delayed age of onset of egg production, and a considerable proportion of LWS females never mature $[49,50]$. Delayed sexual maturity for LWS females were attributed to anorexia because it was possible to induce egg laying by force-feeding. Moreover, sexually matured LWS females were heavier at 56 days of age than those that did not show sexual maturation later in life [51]. Other studies have also indicated a relationship between viral integration and traits related to reproduction. Gavora et al [10] reported that certain virusproducing $e v$-loci, ev-10 or 19 and 12, and silent gene $e v$ 1 can affect egg productivity for layers. Also, the total number of $e v$-loci per genome was significantly related to body weight at first egg and mature body weight [52]. The body weight of LWS juvenile females is related to that of sexually matured LWS females and sexual maturation might be related to the number of ALVE integration and the ALVE expression. Therefore, it is not surprising that high expression of ALVE is correlated to the low juvenile body weight in female chickens.

Quantitative trait locus (QTL) analysis has been performed after crossing the HWS and LWS lines and more than 13 growth-related QTLs were identified all with minor individual effects $[16,53]$ and a high degree of epistasis [54]. Although the exact location of ALVE integrations remain to be defined, our results are consistent with the QTL data in that we present data that multiple proviral loci together contribute to one aspect of the phenotype, namely to the low weight of pullets.

\section{Conclusion}

Artificial selection for high or low juvenile body weight was associated with high frequency and elevated expression levels of ALVE loci in the LWS line. Although the genomic location remains ambiguous, it is most likely that ALVE loci were genetically inherited from both HWS and LWS chickens. Analysis of the advanced intercross line demonstrated significant correlation between low body weight and high ALVE expression. The results showed that while LWS chickens have accumulated more ALVE integrations than HWS ones, only a few of the integrations contribute to the high expression levels observed in the LWS line. High ALVE expression among $\mathrm{F}_{9}$ birds was significantly correlated with low body weight for the females but not for males. The conserved correlation between high expression and low body weight in females after 9 generations of intercrosses, indicated that ALVE loci conferring high expression are genetically linked to or constitute in part the loci for a low body weight of the pullets. 


\section{Competing interests}

The authors declare that they have no competing interests.

\section{Authors' contributions}

SKa did all experimental work and contributed to the writing of the manuscript. SKe contributed to PCR amplifications, TVB typing as well as the sequence analysis. LB and UL did the integration analysis. PBS produced the chicken lines and conceived the project together with LA and FH. FH and LA supervised the work and FH wrote the manuscript. All authors read and approved its final version.

\section{Acknowledgements}

The authors would like to express gratefulness to all colleagues contributed to this work; Joakim Lundeberg to provide with cDNA microarray facility and to participate in conceiving of the study, Fateema Parveen and Daniel Hagey for carrying out part of practical experiments, Carolyn Fitzsimmons, Carl-Johan Rubin, Lina Strömstedt for invaluable discussion about chicken genetics and the data analysis. This work was supported by the Swedish research council, Wallenberg Consortium North "Fun chick", Swedish Foundation for Strategic Research, FORMAS and Arexis AB.

\section{References}

I. Calabotta DF, Cherry JA, Siegel PB, Jones DE: Lipogenesis and lipolysis in fed and fasted chicks from high and low body weight lines. Poult Sci 1985, 64:700-704.

2. Denbow DM, Van Krey HP, Siegel PB: Selection for growth alters the feeding response to injections of biogenic amines. Pharmacol Biochem Behav 1986, 24:39-42.

3. Kuo AY, Cline MA, Werner E, Siegel PB, Denbow DM: Leptin effects on food and water intake in lines of chickens selected for high or low body weight. Physiol Behav 2005, 84:459-464.

4. Kuo AY, Lee JC, Magnin G, Siegel PB, Denbow DM: Differential autonomic nervous system response in obese and anorexic chickens (Gallus gallus). Comp Biochem Physiol B Biochem Mol Biol 2006, I44:359-364.

5. Dunnington EA, Siegel PB: Long-term divergent selection for eight-week body weight in white Plymouth rock chickens. Poult Sci 1996, 75: I 168-II79.

6. Burkhart CA, Cherry JA, Van Krey HP, Siegel PB: Genetic selection for growth rate alters hypothalamic satiety mechanisms in chickens. Behav Genet 1983, 13:295-300.

7. Ka S, Lindberg J, Stromstedt L, Fitzsimmons C, Lindqvist N, Lundeberg J, Siegel PB, Andersson L, Hallbook F: Extremely Different Behaviours in High and Low Body Weight Lines of Chicken are Associated with Differential Expression of Genes Involved in Neuronal Plasticity. J Neuroendocrinol 2009, 2I:208-216.

8. Crittenden LB: Retroviral elements in the genome of the chickens: implications for the poultry genetics and breeding. Critical reviews in poultry biology 1991, 3:73-109.

9. Kuhnlein U, Sabour M, Gavora JS, Fairfull RW, Bernon DE: Influence of selection for egg production and Marek's disease resistance on the incidence of endogenous viral genes in White Leghorns. Poult Sci 1989, 68: 1161-1167.

10. Gavora JS, Kuhnlein U, Crittenden LB, Spencer JL, Sabour MP. Endogenous viral genes: association with reduced egg production rate and egg size in White Leghorns. Poult Sci I99I, 70:618-623.

II. Weiss RA: The discovery of endogenous retroviruses. Retrovirology 2006, 3:67.

12. Gavora JS, Kuhnlein U, Spencer JL: Absence of endogenous viral genes in an inbred line of Leghorn chicks selected for high egg production and Marek's disease resistance. J Anim Breeding Genet 1989, 106:217-224.

13. Kuhnlein U, Gavora JS, Bernon DE, Sabour MP: Incidence of endogenous viral genesin two strainsof White Leghorn chickens selected for egg production and susceptibility or resistance ti Marek's disease. Theor Appl Genet 1989, 77:.
14. Lamont SJ, Chen Y, Aarts HJ, van der Hulst-van Arkel MC, Beuving G, Leenstra FR: Endogenous viral genes in thirteen highly inbred chicken lines and in lines selected for immune response traits. Poult Sci 1992, 71:530-538.

15. Sabour MP, Chambers JR, Grunder AA, Kuhnlein U, Gavora JS: Endogenous viral gene distribution in populations of meattype chickens. Poult Sci 1992, 7 I: I259-1270.

16. Jacobsson L, Park HB, Wahlberg P, Fredriksson R, Perez-Enciso M, Siegel PB, Andersson L: Many QTLs with minor additive effects are associated with a large difference in growth between two selection lines in chickens. Genet Res 2005, 86: I I5- 125.

17. Liljedahl L, Kolstad N, Soerensen P, Maijala K: Scandinavian selection and crossbreeding experiment with laying hens, I. Background and general outline. Acta Agric Scand 1979, 29:273-285.

18. Kerje S, Carlborg O, Jacobsson L, Schutz K, Hartmann C, Jensen P, Andersson $\mathrm{L}$ : The twofold difference in adult size between the red junglefowl and White Leghorn chickens is largely explained by a limited number of QTLs. Anim Genet 2003, 34:264-274.

19. Rubin CJ, Lindberg J, Fitzsimmons C, Savolainen $P$, Jensen $P$, Lundeberg J, Andersson L, Kindmark A: Differential gene expression in femoral bone from red junglefowl and domestic chicken, differing for bone phenotypic traits. BMC Genomics 2007, 8:208.

20. Schutz K, Kerje S, Carlborg O, Jacobsson L, Andersson L, Jensen P: QTL analysis of a red junglefowl $\times$ White Leghorn intercross reveals trade-off in resource allocation between behavior and production traits. Behav Genet 2002, 32:423-433.

21. Miller SA, Dykes DD, Polesky HF: A simple salting out procedure for extracting DNA from human nucleated cells. Nucleic Acids Res 1988, 16:1215.

22. Zhang HM, Bacon LD, Cheng HH, Hunt HD: Development and validation of a PCR-RFLP assay to evaluate TVB haplotypes coding receptors for subgroup $B$ and subgroup $E$ avian leukosis viruses in White Leghorns. Avian Pathol 2005, 34:324-331.

23. Fitzsimmons CJ, Savolainen P, Amini B, Hjalm G, Lundeberg J, Andersson $L$ : Detection of sequence polymorphisms in red junglefowl and White Leghorn ESTs. Anim Genet 2004, 35:39|-396.

24. Savolainen P, Fitzsimmons C, Arvestad L, Andersson L, Lundeberg J: ESTs from brain and testis of White Leghorn and red junglefowl: annotation, bioinformatic classification of unknown transcripts and analysis of expression levels. Cytogenet Genome Res 2005, I I I:79-87.

25. Crittenden LB, Smith EJ, Fadly AM: Influence of endogenous viral (ev) gene expression and strain of exogenous avian leukosis virus (ALV) on mortality and ALV infection and shedding in chickens. Avian Dis 1984, 28:1037-1056.

26. Smith EJ, Crittenden LB: Genetic cellular resistance to subgroup $E$ avian leukosis virus in slow-feathering dams reduces congenital transmission of an endogenous retrovirus encoded at locus ev2 I. Poult Sci 1988, 67:1668-1673.

27. Smith EJ, Salter DW, Silva RF, Crittenden LB: Selective shedding and congenital transmission of endogenous avian leukosis viruses. J Virol 1986, 60:1050-1054.

28. Weiss RA: Cellular receptors and viral glycoproteins involved in retrovirus entry. In The retroviridae Edited by: Levy JA. New York: Plenum Press; 1993: I-108.

29. Adkins HB, Brojatsch J, Young JA: Identification and characterization of a shared TNFR-related receptor for subgroup $B, D$, and $E$ avian leukosis viruses reveal cysteine residues required specifically for subgroup E viral entry. J Virol 2000, 74:3572-3578.

30. Brojatsch J, Naughton J, Adkins HB, Young JA: TVB receptors for cytopathic and noncytopathic subgroups of avian leukosis viruses are functional death receptors. J Virol 2000, 74: I I 490-I | 494

31. Barnard RJ, Young JA: Alpharetrovirus envelope-receptor interactions. Curr Top Microbiol Immunol 2003, 28 I: 107-I 36.

32. Crittenden LB, Motta JV: The role of the tvb locus in genetic resistance to RSV(RAV-O). Virology 1975, 67:327-334.

33. Boyce-Jacino MT, O'Donoghue K, Faras AJ: Multiple complex families of endogenous retroviruses are highly conserved in the genus Gallus. J Virol 1992, 66:4919-4929.

34. Weiss RA, Mason WS, Vogt PK: Genetic recombinants and heterozygotes derived from endogenous and exogenous avian RNA tumour viruses. Virology 1973, 52:535-552. 
35. Sacco MA, Flannery DM, Howes K, Venugopal K: Avian endogenous retrovirus EAV-HP shares regions of identity with avian leukosis virus subgroup $J$ and the avian retrotransposon ART-CH. J Virol 2000, 74: 1296-I306.

36. Venugopal K: Avian leukosis virus subgroup J: a rapidly evolving group of oncogenic retroviruses. Res Vet Sci 1999, 67:113-119.

37. Brown DW, Robinson HL: Influence of avian leukosis viral sequences on transmission to the egg and embryo. Virology 1989, 169:222-226.

38. Robinson HL, Eisenman RN: New findings on the congenital transmission of avian leukosis viruses. Science 1984, 225:417-419.

39. Zhang HM, Bacon LD, Heidari M, Muir WM, Groenen MA, Zhang Y, Wong GK, Fulton JE, O'Sullivan NP, Albers GA, et al.: Genetic variation at the tumour virus $B$ locus in commercial and laboratory chicken populations assessed by a medium-throughput or a high-throughput assay. Avian Pathol 2007, 36:283-291.

40. Smith EJ, Fadly AM: Male-mediated venereal transmission of endogenous avian leukosis virus. Poult Sci 1994, 73:488-494.

4I. Benkel BF: Locus-specific diagnostic tests for endogenous avian leukosis-type viral loci in chickens. Poult Sci 1998, 77:1027-1035.

42. Chang CM, Coville JL, Coquerelle G, Gourichon D, Oulmouden A, Tixier-Boichard M: Complete association between a retroviral insertion in the tyrosinase gene and the recessive white mutation in chickens. BMC Genomics 2006, 7:19.

43. Bosinger SE, Hosiawa KA, Cameron MJ, Persad D, Ran L, Xu L, Boulassel MR, Parenteau M, Fournier J, Rud EW, Kelvin DJ: Gene expression profiling of host response in models of acute HIV infection. J Immunol 2004, 173:6858-6863.

44. Giri MS, Nebozhyn M, Showe L, Montaner LJ: Microarray data on gene modulation by HIV-I in immune cells: 2000-2006. J Leukoc Biol 2006, 80: 1031-1043.

45. Masker K, Golden A, Gaffney CJ, Mazack V, Schwindinger WF, Zhang W, Wang LH, Carey DJ, Sudol M: Transcriptional profile of Rous Sarcoma Virus transformed chicken embryo fibroblasts reveals new signaling targets of viral-src. Virology 2007, 364: $10-20$

46. von Schwedler UK, Stuchell M, Muller B, Ward DM, Chung HY, Morita E, Wang HE, Davis T, He GP, Cimbora DM, et al.: The protein network of HIV budding. Cell 2003, I | 4:70I-7I3.

47. Morita E, Sundquist WI: Retrovirus budding. Annu Rev Cell Dev Biol 2004, 20:395-425

48. Joliot V, Martinerie C, Dambrine G, Plassiart G, Brisac M, Crochet J, Perbal B: Proviral rearrangements and overexpression of a new cellular gene (nov) in myeloblastosis-associated virus type I-induced nephroblastomas. Mol Cell Biol I992, I 2: I0-2I.

49. Zelenka DJ, Jones DE, Dunnington EA, Siegel PB: Selection for body weight at eight weeks of age. 18. Comparisons between mature and immature pullets at the same live weight and age. Poult Sci 1987, 66:41-46.

50. Zelenka DJ, Siegel PB, Dunnington EA, Cherry JA: Inheritance of traits associated with sexual maturity when populations of chickens reach 50\% lay. Poult Sci 1986, 65:233-240.

51. Siegel PB, Dunnington EA: Selection for growth in chickens. CRC critical reviews in poultry biology 1987, I:I-24.

52. Iraqi F, Darvas A, Zeitlin G, Beckmann J, Soller M: Nonlinear effects of chicken endogenous viruses on body weight may be responsible for maintaining these elements in a stable genetic polymorphism. Poult Sci 1994, 73:1625-1632.

53. Park HB, Jacobsson L, Wahlberg P, Siegel PB, Andersson L: QTL analysis of body composition and metabolic traits in an intercross between chicken lines divergently selected for growth. Physiol Genomics 2006, 25:216-223.

54. Carlborg O, Jacobsson L, Ahgren P, Siegel P, Andersson L: Epistasis and the release of genetic variation during long-term selection. Nat Genet 2006, 38:418-420.

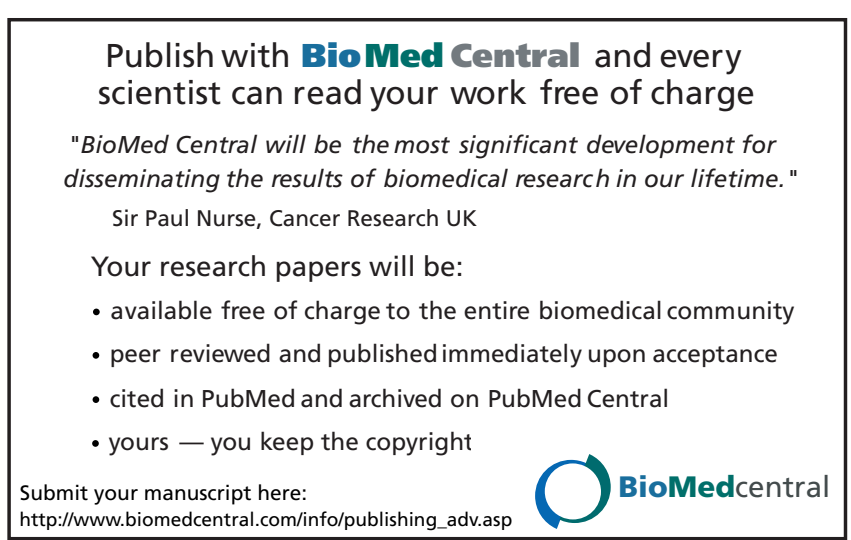

